\title{
Republicanism: An Unattractive Version of Liberalism
}

\author{
CARLA SAENZ \\ (University of North Carolina at Chapel Hill)
}

\begin{abstract}
Philip Pettit is the most important contemporary advocate of the republican tradition in political philosophy. He advances a concept of freedom as non-domination, and contrasts it with the liberal conception of freedom as non-interference. He claims that two features distinguish domination from interference: (1) The capacity of interference (as opposed to actual interference), and (2) the fact that the interference is arbitrary. I shall argue that Pettit's republicanism is not sufficiently different from liberalism to count as a genuine alternative to it. First, (1) does not set apart republicanism from liberalism, certainly not from John Rawls's liberalism. The only relevant difference between republicanism and liberalism is related to (2): the notion of arbitrariness. Yet this difference makes republicanism an unattractive version of liberalism, insofar as it, paradoxically, allows for republicanism to legitimize a grave form of domination, paternalism, and, in general, domination coming from the state. This problem gets exacerbated by Pettit's consequentialist framework.
\end{abstract}

There has recently been a revival of the republican tradition in political philosophy. Philip Pettit is the most important contemporary republican theorist (hereafter: republican). He advances a concept of freedom defined in terms of non-domination, which he contrasts with the liberal conception of freedom as non-interference. I shall argue that Pettit's republicanism is not sufficiently different from liberalism to count as a genuine alternative to liberalism. More importantly, its differences from John Rawls's liberalism make it a less attractive version of liberalism. Republicanism, paradoxically, legitimizes a grave form of domination, paternalism, and, in general, domination coming from the state. This problem is exacerbated because of Pettit's consequentialist framework.

\section{Republican Freedom as Non-Domination}

Republicanism advances freedom as non-domination, which is presented as an alternative to the notions of negative and positive freedom described by Isaiah Berlin: Negative freedom is absence of interference, and positive freedom is 'self-mastery,' 'self-control' or 'self determination. ${ }^{1}$ In the republican tradition freedom is conceived as absence of mastery by others, that is, as nondomination. Domination is exemplified by the relation between master (dominus) to servant or slave. Non-domination hence involves a certain status of equality, which Pettit repeatedly depicts with the metaphor of agents being able to "look the other in the eye." Pettit defines domination as "subjection to an arbitrary power of interference on the part of another - a dominus or mastereven another who chooses not actually to exercise that power" $(2002,340)$. Non-domination thus differs from non-interference, which is the absence of actual coercion or obstruction. 
Liberal freedom as non-interference and republican freedom as non-domination constitute different ideals according to Pettit, because interference and domination are "different evils" (1997, 22): It is possible to have domination without interference, as well as interference without domination. An individual can be dominated by a kind master who does not actually interfere with his servant's choices. Absence of interference is not good enough because actual non-interference could be the lucky result of a precarious contingency. Such an individual would be still exposed to the possibility of interference by her kind master. If freedom is conceived as non-domination, this contingency is avoided, according to Pettit; the possibility of interference is ruled out by the fact that the agents are secured against it.

Similarly, it is possible to undergo interference without being dominated, that is, without relating to anyone in the fashion of servant. According to Pettit, when interference is meant to further the agents' interests, then such interference is non-arbitrary so it does not constitute domination. Such is the case of the non-dominating interference of the law. Non-domination does not just outlaw the capacity for interference, but the capacity for non-arbitrary interference. What makes an act of interference arbitrary? Pettit acknowledges that arbitrariness can be defined in both a procedural and in a substantive sense. In the procedural sense an act is arbitrary if it is chosen (or rejected) at the agents' pleasure, without reference to the interests of those affected. In the substantive sense an act is arbitrary if it goes against the interests of the persons affected. Pettit endorses the substantive sense. ${ }^{3}$ He specifies that it is at least necessary to track the relevant interests of the persons affected. "My relevant interests and ideas," Pettit explains, "will be those that are shared in common with others, not those that treat me as exceptional, since the state is meant to serve others as well as me" (1997, 55-6). Thus, the interference perpetrated by the state is non-arbitrary as long as it furthers the relevant interests shared by those affected. ${ }^{4}$

According to Pettit, non-domination is not merely necessary but sufficient for an account of freedom. That is, in his opinion freedom can be defined exclusively as non-domination. This fact does not mean that non-interference is unimportant. In Pettit's view non-interference is subordinated to freedom as non-domination $(1997,75-5 ; 2002,342-5)$. He argues,

\footnotetext{
Even if domination is the only antonym of freedom, it is still going to follow according to my analysis that undominating or nonarbitrary interference -in particular the interference suffered in living under a coercive but fair rule of law- must count as a secondary offence against freedom. Such a rule of law will not compromise freedom, in the manner of a dominating agency, but it will condition freedom (...), it will reduce the range or ease with which people enjoy undominated choice $(2002,342$; his emphasis).
}

While domination alone compromises freedom, Pettit claims, a number of factors condition 
it insofar as they limit one's ability to exercise freedom. The factors that condition freedom, such as non-arbitrary intentional interferences and natural obstacles, like poverty, must be minimized in order for freedom to be effective (as opposed to merely formal). That is, formal republican freedom requires non-domination, while effective republican freedom requires also the minimization of interference. Pettit acknowledges that the law, and in general interference from the state, condition freedom yet do not compromise it $(1997,75-7)$.

Quentin Skinner has argued, pace Pettit, that claims that the republican ideal of freedom involves both non-domination and non-interference as equally important concerns (Skinner 1998, 68-9 and 83-4). As Pettit observes $(2002,342)$ this disagreement is not substantial; it only amounts to a different way of ranking the following four possible scenarios:

1. Neither interference nor domination

2. Both interference and domination

3. Domination without interference

4. Interference without domination

Pettit claims that the third will be worse than the fourth, while Skinner thinks that 3 and 4 are equally bad. ${ }^{5}$ Pettit claims that his way of ranking the scenarios fits better with the position of the traditional republican authors; Skinner disagrees.

Furthermore, republicanism is, as advanced by Pettit, a consequentialist theory as opposed to a deontological theory $(1997,97-102)$. Non-domination, he argues, is a goal that the state should promote (maximize) instead of a constraint it must honour. He concedes that this can be problematic:

If the promotion of non-domination required resort to institutional arrangements and strategies that proved intuitively repulsive to our moral sense, then we might well wonder whether non-domination really was an adequate political ideal or, if we remain confident on that point, whether the appropriate policy really was one of promoting the ideal rather than honouring it (1997, 102; my emphasis).

Pettit's solution to this conflict appeals to the test of reflective equilibrium. The rationale goes like this: If the promotion of non-domination requires morally objectionable arrangements, then non-domination is an unattractive ideal. However, the ideal of non-domination passes the test of reflective equilibrium, which means that the ideal proves to fit with our moral judgments. Therefore, the ideal of non-domination is attractive. ${ }^{6}$ 


\section{Does Republicanism Really Differ from Liberalism?}

I claim that republicanism is not sufficiently different from Rawls's liberalism to count as a different kind of theory. In particular, freedom as non-domination does not distinguish republicanism from liberalism. Let's consider the two features that Pettit introduced in order to distinguish domination from interference: (A) The capacity for interference (as opposed to actual interference), and (B) the fact that the interference is arbitrary. The first one articulates the possibility of domination without interference, while the second one articulates the possibility of interference without domination. I begin with (A).

Liberals are not only concerned with actual interference but also with domination as potential interference. ${ }^{7}$ As observed by Dudley Knowles (1999), Erin Kelly (1999), John Christman (1998), and Roger Boesche (1998) liberals also worry about the possibility that someone may have the capacity to interfere with another. ${ }^{8}$ Insofar as potential interference constitutes a threat to freedom it can be seen as a type of constraint against which liberals also want to protect citizens (Christman 1998, 203). In general, the law is meant to guarantee that nobody has the possibility of interfering (Knowles 1999, 416, 418). More importantly, egalitarian liberals are clearly concerned with this aspect of domination since they advance "equal freedom," that is, they are simultaneously explicitly concerned with both freedom and equality.

Pettit insist that in order to achieve non-domination it is imperative to guarantee that nobody is at the mercy of the other, that is, that there is no asymmetry of status. ${ }^{9}$ Domination is then, Pettit repeatedly observes, a matter of status, as opposed to the result of specific actions given that a gentle master might decide not to act in ways that interfere with his servant and still dominate her. ${ }^{10}$ The condition in which there is no asymmetry of status is a condition of equality. That is why Pettit mentions the importance of the strategy of reciprocal power in order to achieve non-domination: "The strategy of reciprocal power is to make the resources of dominator and dominated more equal" (1997, 67, my emphasis). Pettit adds that freedom as non-domination "displays a distinctively egalitarian character" $(1997,111)$. In order to achieve non-domination it is thus necessary to guarantee equality between the citizens: "The equality sought required an equality before the law and before whatever instruments were available for asserting people's freedom as non-domination” $(1997,117)$.

Egalitarian liberals' concern with equality is meant to secure that status in which, using Pettit's metaphor, "everybody can look at each other in the eye": A status of non-domination. Insofar as they advance freedom and equality, egalitarian liberals advance non-domination. It is then not true that "the ideal [of freedom as non-domination] is distinctively egalitarian" (Pettit 1997, 110, my italics); it does not distinguish republicanism from alternative theories is its egalitarian character. As a matter of fact, the most important alternative theory, liberalism, is also egalitarian. ${ }^{11}$

Furthermore, it seems that Rawls's egalitarian liberalism accounts better for equality insofar 
as it is more specific and details how precisely it relates to other aspects of the theory. Rawls's second principle of justice is strongly egalitarian. It includes not just the principle of fair equality of opportunity but also the difference principle, according to which inequalities are justified if they work for the advantage of the worst-off groups. Moreover, Rawls specifies how the different principles relate to each other, and gives guidance for their application, for instance through the development of an index of primary goods to identify the people that are worse-off. On the contrary, Pettit's metaphor of "looking at each other in the eye" is too vague to bear theoretical weight. ${ }^{12} \mathrm{He}$ certainly mentions that his theory is committed to structural but not to material egalitarianism; yet it is still not clear how these particular demands relate to other aspects of his theory, or why freedom as non-domination necessitates one type of equality and not the other. ${ }^{13}$

We can see the desire of liberals to protect people against domination more clearly if we consider Rawls's egalitarian liberalism. Non-domination is deeply embedded in the rationale of the original position, which is the hypothetical condition in which people agree on principles of justice. In the original position the persons are behind a veil of ignorance, that is, without knowing their own position in society. Since behind the veil of ignorance a person does not know whether she may be actually interfered with or not, by necessity she has to focus on the potential exposure to interference. ${ }^{14}$ Republicanism thus seems to collapse into liberalism. ${ }^{15}$ Pettit does not acknowledge the relevance of this particular aspect of Rawls's liberalism, although he repeatedly points out the similarities between his own theory and Rawls's, and contrasts both with libertarianism, which is the specific target of his critiques because it justifies inequality.

Liberalism is concerned with both non-interference and non-domination, so it seems to be closer to Skinner's republicanism than to Pettit's. As mentioned above, Pettit subordinates interference to domination. He argues that it is worse to suffer domination without interference (third scenario above) than interference without domination (fourth scenario). It is certainly not obvious that that is true. Most people would agree that, even if domination (without interference) is politically worse, it is factually better than interference. Pettit claims that such was the view of classical republican authors, and further offers the following example to support his claim. In a crime of assault there is both domination and interference. Pettit analyzes it in the following way in order to show that domination is worse than interference:

We can distinguish in any such case between the evil associated with the domination assumed by the criminal and the distinct evil associated with the reduction of choice by the criminal's interference. While a victim generally suffers reduced choice as a result of crime -say, that involved in loss of money, traumatisation, or physical harm - this is the sort of effect that might have come about as a result of an unintended accident. The evil of reduced choice is certainly important, but it is distinct from the evil involved in the 
assumption and exercise of domination by the criminal; it is this evil that explains why, intuitively, it is worse to have one's choices reduced by crime than by an unintended, perhaps purely natural, accident (Pettit 2002, 344, my italics).

His discussion of these examples is not persuasive. The evil of interference that the victim suffers is not merely "a reduction of choice," as Pettit tendentiously says, but active coercion. The victim was left with no choice (say, no choice to keep her money) and furthermore harmed by her attacker. Hence it is not "the sort of effect that might have come about as a result of an unintended [perhaps purely natural] accident," and it is then plausible that it is worse than the domination by the criminal.

Besides, it is not even clear that a crime of this sort necessarily entails domination by the criminal. We can conceive of a robbery in which the criminal simply sneaks the money from the victim, who never notices its absence. In this case the criminal has not related to the victim "in the fashion of a master." It seems that in order to use this example to support his claim that domination is worse than interference, Pettit would need to explain the example more precisely as well. At any rate, Pettit himself acknowledges that this difference between his version of republicanism and Skinner's (which seems to be closer to liberalism) is not deep (Pettit 2002, 342).

Furthermore, even if we grant Pettit that it is worse to suffer domination than to suffer interference, it is not clear what exactly the relationship between these "two evils" is. Pettit claims that non-arbitrary or non-dominating interference does not "compromise" freedom yet it "conditions" it $(2002,342)$. How does "conditioning" differ from "compromising"? Why does Pettit consider interference a "secondary offence" against freedom even if it does not involve domination? While Pettit claims that non-arbitrary, that is, non-dominating interference is justified, his discussion about interference suggests also that non-arbitrary interference is not justified after all, because it does constitute an offence against freedom. The problem is that these claims do not seem consistent with each other.

Pettit claims that republicanism is superior to liberalism because republicanism is "distinctively communitarian" $(1997,110)$. He does not mean that republicanism amounts to communitarianism, as Michael Walzer, Alaisdair McIntyre, Charles Taylor, and Michael Sandel, and others understood it. These communitarians advance a positive account of freedom as self-mastery from which Pettit explicitly dissociates himself. ${ }^{16}$ Rather Pettit claims that for the good to be communitarian it needs to be both social and common $(1997,121)$. Pettit maintains that:

A good will be social to the extent that its realization presupposed the existence of a number of people who display intentional attitudes and perhaps intentional activities. (...) A good 
will be common to the extent that it cannot be increased (or decreased) for other members of the relevant group without at the same time being increased (or decreased) for other members of the group $(1997,121)$.

With respect to the social character of the good, Pettit's definition is too weak. If republican freedom as non-domination is social by the mere fact that the existence of a small number of people is presupposed, then republicanism is no different in this respect from liberalism, which also presupposes such a thin social world. In fact, in the absence of such minimal human interaction social life would not exist so no political theory would be necessary.

As for Pettit's definition of what makes a good 'common,' it is not clear that doing something for the common good will directly and equally benefit everybody in society. Most likely, it will not. For instance, we consider cleaning a polluted creek as something that we do for the common good, yet it is not the case that such action will be equally beneficial for everyone in society: The people living in the creek's neighborhood will certainly benefit more than people that do not live close to it and do not even frequent the creek. However, it is not necessary to deepen our analysis about what makes a good "common," for Pettit's discussion takes a very peculiar path. In order to show the common character of the republican good, Pettit advances the idea of "vulnerability class": If others in your situation are exposed to arbitrary interference, you are exposed as well. "You will only enjoy non-domination, therefore, so far as non-domination is ensured for those in the same vulnerability class as you" $(1997,122)$. For instance, in a society where women are not protected, "womanhood is a badge of vulnerability." $(1997,123)$ Even if a particular woman is treated well, she is at risk of arbitrary interference.

Pettit claims that freedom as non-domination depends on how other persons in your group are situated because it is concerned with the possibility of interference as opposed to the actual interference that particular individuals suffer $(1997,124)$. Politics promoting the ideal of nondomination is therefore common: "it will have to be articulated at the level of group grievances and group assertion, as well as at the levels involving individuals as such" $(1997,124) .{ }^{17}$ Achieving non-domination is thus a "solidaristic cause here, not just a sum of individual causes" $(1997,124)$. To that extent it differs from freedom as non-interference, which Pettit deems an atomistic good insofar as it promotes policies focus on individuals instead of on groups.

It is not clear that the mere recognition of vulnerability classes, which are a fact of life, is sufficient to call for the solidarity that Pettit asks for, which requires some sort of empathy. Even assuming it is, there would be solidarity between the members of one vulnerability class, and not between members of different vulnerability classes. ${ }^{18}$ Rawlsian liberalism, which, as said before, is concerned with domination as the possibility of interference, does better bringing about this solidarity among all citizens. Behind the veil of ignorance you are potentially in any vulnerability class. Moreover, the fact that principles of justice are chosen in the original position effectively 
articulates the notion of vulnerability classes with the policies that rule society. Rawls's egalitarian liberalism does therefore a better job furthering a communitarian ideal.

At any rate, it seems that, independently of the notion of freedom that is being promoted, it is impossible for any policy not to be common in the sense Pettit proposes: State policies do not target particular individuals but can only possibly focus groups of people under similar relevant conditions.

What then sets apart republicanism from liberalism? It is not, pace Pettit, (A) the fact that republicanism protects individuals against the possibility of interference. If there is any relevant difference between republicanism and Ralwsian egalitarian liberalism, it has to be related to (B) the republican notion of arbitrariness, which according to Pettit articulates the possibility of interference without domination. At any rate, the fact that republicanism is not substantively different from liberalism is in itself not a problem; I believe that liberalism is a correct theory. Rather, it is problematic insofar as Pettit claims that republicanism is an alternative to liberalism.

\section{Arbitrariness, Paternalism, and Domination Coming from the State}

A worse problem for Pettit's theory is that it legitimizes paternalism. Historically, as observed by Kapust (2004), republicanism has been compatible with paternalism. Patricians treated plebeians paternalistically. It was assumed that patricians knew better than the plebeians themselves what was in their best interest. I am taking for granted that paternalism is a bad thing: If one party acts like the father (pater) while the other is treated as the child, it is implied that there is no equality between both. Yet competent adults ought to be treated like equals in the relevant respects. Respect requires such treatment. For one to act as if one were superior to the other shows a lack of respect for the other party. I think this constitutes an instance of domination.

Freedom as non-domination is in Pettit's theory compatible with paternalistic interference insofar as interference that furthers the ideas and interests of those affected is acceptable under this ideal. As explained above, Pettit refers to two different senses of arbitrariness, procedural and substantive. Although he does not try to harmonize them (Meyerson 1999, 174) he clearly opts for the substantive sense, according to which interference is arbitrary if it fails to track the relevant ideas and interests of those subject to it. Pettit's definition of arbitrary interference rests on the following assumptions: First, that it is possible to track the relevant ideas and interests of those affected by the interference, namely the citizens. Second, that those affected (again, the citizens) share relevant ideas and interests. These assumptions are in Pettit's view interrelated for, as mentioned above, he claims that the relevant ideas and interests of citizens are those that are shared in common with others. ${ }^{19}$ These assumptions are certainly questionable. Particularly within the 
context of a multiculturalist society, it is not evident that any of those assumptions or the peculiar connection between both are true. For instance, citizens of different religions disagree about ideas and interests that they consider relevant. A group of Christians might think that their relevant ideas and interests are those related to their religion, which they do not share with citizens of other religious or non-religious groups.

Let us however grant Pettit that these assumptions are true in order to focus on my main claim about paternalism. Interference is for Pettit not arbitrary if it tracks the relevant ideas and interests of those affected. ${ }^{20}$ According to this, if someone is being interfered with in a way that furthers her interests, then such interference is non-arbitrary and thus justified because it does not constitute domination. First, if interference is justified only as long as it furthers the agents' interests, it seems that we cannot justify actions that we consider justified, like imprisoning criminals: Imprisoning them is against their interest.

Second, we can easily conceive of cases that would be unanimously considered instances of domination, in which the dominated party believes that such interference is in her best interest. Traditional gender-based domination, as well as numerous cases of ethnicity-based domination (clearly in countries with a colonial background) fit that pattern. The dominated parties are told that the interference they are suffering is ultimately furthering their own interests. For instance, natives in Latin America were told (and eventually convinced) that the imposition of religious beliefs was in their best interest because it would make their salvation possible.

According to Pettit's account such paternalistic interference is justified because it does not count as domination. Since arbitrariness is defined with reference to individuals' interests, paternalism is implicitly legitimized. Someone might object, on behalf of Pettit, that gender-based domination and colonialism themselves cannot possibly be in the interest of the people concerned. Yet on what basis could Pettit justify that claim? He has not provided with any conceptual resources to answer to that question. And the question is not trivial. It has been recently and repeatedly argued in favor of apartheid in South Africa, that racial segregation was in the best interest of the segregated population because a regime led by white people was politically and economically more stable and thus was leading to better life conditions than one led by blacks.

Furthermore, it is possible for another individual or the state to claim that they know better how to further my ideas and interests, which would justify their interference given that such interference will not even count as arbitrary. For instance, it can be argued that it is in the interest of Americans not to drink soda and to exercise for one hour each day. According to Pettit's theory, the government would be justified in banning sodas and forcing people to exercise because it is in their best interest to do so. ${ }^{21}$

Pettit admits some problematic aspects of his definition of arbitrariness. For instance, he acknowledges that these questions are difficult to answer: How do we know that the interests that 
are being promoted are those that everyone would identify as relevant? How do we guarantee that the interest is not sectional or factional? Pettit recognizes the practical necessity of public discussion in which people speak for themselves and express their own interests $(1997,56)$. Every idea should be open to challenge. What constitutes a common interest, Pettit states, is therefore a "political issue," about which political theorists are not competent to decide beforehand (1997, 56-7). However, he admits that it is possible that some individuals cannot speak for themselves $(1997,60)$. This is a damaging admission because if some individuals cannot speak for themselves and hence be in fact dominated, then it seems that it is not true that what constitutes the common interest and thus amounts to non-domination is a "political issue" but one that theorists can in fact identify beforehand.

Pettit explicitly states that consent is not a sufficient guard against arbitrariness: "What is required for non-arbitrariness in the exercise of a certain power is not actual consent but the permanent possibility of effectively contesting it" $(1997,63)$. Yet this brings us again to paternalism because some domination is not contested by some of those who are subjected to it because they might mistakenly believe that the domination furthers their interests. It is then not clear that possible contestation can be the ultimate guard against arbitrariness (and thus against domination).

The problem with paternalism is not merely that it constitutes some sort of "undesirable side effect." Rather, it is that paternalism is a type of domination in which one of the parties (the dominating one) has wrongfully assumed the authority to judge what is in the best interest of the other party based on the belief that the inferior party is incompetent, or at least not as competent as the dominating party. The essential inequality that characterizes domination is evident. Pettit's attempt to secure individuals against domination has paradoxically legitimized a serious form of it.

In fact, history constantly shows that the state has been an oppressive source of arbitrary interference, whether paternalistically masked under alleged non-arbitrariness or not. People in government often use the state's power and resources to promote their own moral or religious views, thereby dominating others. The fact that it is very hard to track the ideas and interests of the citizens makes it even easier: Groups advancing sectional or factional interests will conceal their domination by claiming that they are in fact furthering the interests of the citizenry. Pettit's republicanism cannot prevent this type of scenario; there is no recourse in his theory to rule it out. He certainly acknowledges the possibility of the state threatening freedom as non-domination: "as a state gains the powers necessary to be a more and more effective protector (...) it becomes itself a greater threat to freedom as non-domination than any threat it seeks to remove" $(1997,105)$. However, he does not properly tackle this problem. There is no clarification of what practices are ruled out and on what basis. By not clarifying the limits of the state action on a moral basis, Pettit opens his theory to a serious criticism. Moreover, given that he has claimed that his starting point is a multiculturalist society, he cannot validly reply that he has not determined those limits because they depend on particular cultural traditions. ${ }^{22}$ 
I am not criticizing Pettit on the grounds that the state might actually dominate its citizens. Rather my criticism is that he does not clarify the limits of the state action on a moral basis. No theory of ethics or political philosophy can be considered at fault if the agents (individually or collectively) do what they morally ought not to do. No normative account can prevent that. Normative theories (about what subjects ought to do) are not proven wrong because subjects fail to do what they ought to do. The problem I am pointing out here gets exacerbated because of Pettit's consequentialist framework.

\section{Consequentialism and Its Problems}

Pettit maintains that freedom as non-domination is a goal that the state should maximize as opposed to a constraint it must honour. Yet it is legitimate to ask at what expense we should maximize freedom as non-domination are. Specifically, what should be given up in order to maximize freedom as non-domination? We can certainly conceive of various actions that will never be morally justified no matter how effectively they can promote non-domination. Pettit acknowledges that sometimes the promotion of non-domination might require restricting freedom -"[T] here are cases where a veil has to be drawn, for a moment, over liberty"23 — or other actions that are even "intuitively repulsive to our moral sense" $(1997,102)$, to the point that we "wonder whether non-domination really was an adequate political ideal or, if we remain confident to that point, whether the appropriate policy really was one of promoting the ideal rather than honouring it" (1997, 102). However, Pettit does not specify what the limitations are for morally repulsive or freedom-restricting practices, or on what basis certain practices should be ruled out even if they promote non-domination. Doing so would clearly work against his emphatic consequentialist framework.

Pettit merely appeals to the test of reflective equilibrium, and claims that the ideal of nondomination, which can require morally objectionable arrangements, does pass the test of reflective equilibrium. Yet this begs the question, for it does not address why the promotion of non-domination does not entail morally objectionable arrangements, that is, why it passes the test of reflective equilibrium, which is precisely what is at stake. Pettit does not answer this question or provide an argument to show that freedom as non-domination passes the test of reflective equilibrium, that it, that the arrangements it entails do not conflict with our moral standards; he merely states that it does. ${ }^{24}$ It seems that the only way to provide such appropriate argument is to invoke liberal

principles, which serve as constraints that cannot be overridden in view of any "greater goal," thereby disposing of consequentialism. ${ }^{25}$

Paradoxically, Pettit declares that republicanism has a "potentially universalistic appeal" (1997, 133-4). The republican language of freedom as non-domination can articulate the grievances of causes such as environmentalism, feminism, socialism, and multiculturalism (1997, 131, 133-4 
and ff.). It is a political lingua franca $(1997,131)$. He does not realize that this fact constitutes a serious weakness of republicanism. The problem is not that republican language fails to articulate some "good" concerns, but the fact that that same language can articulate highly immoral concerns as well. He does not explain on what basis we should abstain from morally objectionable arrangements that promote non-domination. He does not identify any sort of restriction for republican language. Unlike political liberalism, which is restricted to "reasonable comprehensive doctrines," there is no discussion about the concerns that republicanism cannot, from a moral perspective, articulate. ${ }^{26}$

Moreover, republicanism's consequentialism can actually work against the concerns that the republican language allegedly can articulate. If non-domination works as a goal and not as a constraint, as Pettit has argued, it can be the case that the best way of advancing non-domination conflicts with some of the causes that republicanism can potentially articulate. Even if republican language can in theory support environmentalist, feminist, multiculturalist, and socialist grievances, that does not guarantee that republican theory will support these causes if doing so is not the best way to promote freedom as non-domination. Republicanism is not committed to these causes in the way that egalitarian liberalism is. If republicanism were committed to supporting the key environmentalist, feminist, multiculturalist, and socialist demands, then they would play some role as constraints in order to avoid that their claims be overridden in view of "some greater goal." And that is not because of liberalism's alleged understanding of freedom as non-interference. The relevant feature is not necessarily non-interference as opposed to non-domination, but the liberal commitment to equality. It is such commitment to equality, in conjunction with its deontological character, that makes political liberalism superior.

Ironically, Pettit's critique of liberalism is a critique of consequentialist liberalism. ${ }^{27}$ By focusing on consequentialist liberalism, Pettit reveals problems that are proper to consequentialism itself, from which his own theory suffers, unlike deontological liberalism. Most of the problems of republicanism are in fact associated with its consequentialism rather than with a particular notion of freedom. Thus, instead of showing the strength of consequentialist republicanism -as compared for instance with deontological liberalism - Pettit's defense exposes its weakness.

\section{Final Remarks}

Although republicanism is presented as an alternative to liberalism, it is not. The distinction between freedom as non-interference and freedom as non-domination, which allegedly distinguishes both theories, is not sufficient to set republicanism apart from liberalism. ${ }^{28}$ In order to achieve freedom as non-domination it is necessary to guarantee equality, which is a core value of liberalism. Since for liberals freedom goes in tandem with equality, they advance 'equal freedom,' which is equivalent to freedom as non-domination. Furthermore, like republican theorists, egalitar- 
ian liberals are strongly committed to advancing non-domination by securing equality not just in the political sense but also in the socio economic one.

Is republicanism's critique merely that liberalism lacks an "umbrella notion" that integrates freedom with equality? If that is the case, then it seems that this is merely a superfluous dispute about words. It is trivial to claim that republicanism is a superior theory because it advances a notion $\mathrm{P}$ whose meaning is determined by notions $\mathrm{Q}$ and $\mathrm{R}$, when $\mathrm{Q}$ and $\mathrm{R}$ are themselves advanced by liberalism. ${ }^{29}$ Moreover, the dispute is related to a historical fact: When the republican tradition was originally developed master / servant relationships constituted an important concern of classical and neo roman theorists. Nowadays contemporary liberal philosophers need not make domination a theme because they assume that people are free and equal. That means that liberals are concerned with domination as an evil, even if they do not explicitly refer to it.

It has been argued that what really sets republicans apart from liberals is their understanding of the law in relationship with freedom. ${ }^{30}$ While liberals hold that any sort of state interference counts as reducing freedom, republicans do not. As long as the laws and state interventions are non-arbitrary, according to republicans they do not reduce the citizens' freedom. They even make their freedom possible. ${ }^{31}$ However, it is not clear that Rawls actually sees law as reducing (not merely conditioning) freedom. At any rate, Pettit still acknowledges that, on the one hand, according to republican theory even the non-arbitrary interference of the law conditions freedom, that is, "law restricts choice, but nonetheless (...) it does not offend straightforwardly against liberty" (2002, 346). He adds, "While the properly constituted law (...) represents a form of interference, it does not compromise people's liberty" $(1997,35)$. On the other hand, Pettit claims that liberals see the law as a way of "taking one step backwards in order to take two steps forward" $(1997,36)$ : While law interferes with freedom and thereby reduces it, "it compensates for the damage done by preventing more interference than it represents" $(1997,35)$. So we can fairly ask how significant is then this difference between the republican and the liberal understanding of law? I fail to see its substance or implication. For one thing, as also observed by Mayerson $(1999,175)$ it seems that it will not be of any relevance in practice.

Republicanism furthers a negative type of freedom for it is the absence of something, namely, of domination. Such negative freedom seems to call for a deontological account. Given that the protection of individuals against domination constitutes the most important concern of republican thinkers, it seems that a deontological account would be crucial because such an account would guarantee that nothing (not even a "greater goal") overrides the protection of each individual. Even if consequentialism makes domination improbable, as Pettit repeatedly claims, it is not improbability but inaccessibility that is required: "domination goes with the accessibility of arbitrary interference to another, and the improbability of the kind in question here does not make for inaccessibility" $(1997,64)$. It seems then that only a deontological approach can guarantee that citizens are truly 
protected against any sort of domination or interference.

Although Pettit gives the impression that republicanism is intrinsically consequentialist, it is not. The consequentialist framework of Pettit's theory is his own contribution to republican tradition. Neither the classical and modern republican theorists are consequentialists nor is Quentin Skinner. ${ }^{32}$ In fact, freedom as non-domination is entirely consistent with deontology. Moreover, a genuine concern with securing freedom as non-domination seems to require a deontological framework. It is possible to do away with Pettit's consequentialist framework, thereby certainly removing some problems of his theory while, by the same token, making the difference between republicanism and liberalism even less substantial. However, that would still not solve other problems of Pettit's theory that are related to his definition of arbitrariness; in particular, the fact that it legitimizes paternalism. ${ }^{33}$ 


\title{
Notes
}

\author{
${ }^{1}$ Berlin 1958.
}

${ }^{2}$ Pettit 1997, 5, 71 and passim. He adds, "[Freedom as non-domination] requires the capacity to stand eye to eye with your fellow citizens" (1997, 5). See also 1997, 63-4, 71.

${ }^{3}$ Pettit specifies that "an act of interference can be arbitrary in the procedural sense intended here -it may occur on an arbitrary basis - without being arbitrary in the substantive sense of actually going against the interests or judgments of the persons affected" (1997, 55).

4 "The state will not interfere on an arbitrary basis (...) so far as its interference has to be guided by certain relevant interests and ideas and those interests and ideas are shared by those affected" (Pettit 1997, 63).

${ }^{5}$ More about this later.

${ }^{6}$ See Pettit 1997, 102.

${ }^{7}$ Roger Boesche has observed that Pettit does not offer any evidence for his claim that liberals are exclusively concerned with actual interference $(1998,863)$.

${ }^{8}$ This might certainly not be true if we consider Hobbes's mechanistic account, which is the one Pettit contrasts his view with, but it seems to be the case with contemporary liberals. Pettit assumes that Hobbes counts as liberal, but that is a highly questionable assumption which I do not think is correct.

${ }^{9}$ Pettit 1997, 25, 31-2, 63-4, 68.

10 "[D]omination will also tend to introduce a characteristic asymmetry of status," Pettit states in 2002, 350. See also Kapust 2004, 383, 388.

${ }^{11}$ Pettit 1997, 110. As part of his discussion about the importance of equality for non-domination, Pettit states:

Some may not be persuaded that the connection between non-domination and equally intense non-domination is as tight as I take it to be. If they are to be substantively faithful to the republican tradition, then (...) such thinkers will have to do with freedom as non-domination what Rawls and many liberals do with freedom as non-interference. They will have to take equal freedom - strictly speaking, equally intense freedom- to be the central concern $(1997,117$, my italics).

This suggests that, by having equal freedom as his main concern, Rawls and egalitarian liberals achieve the same as Pettit with his idea of freedom as non-domination.

${ }^{12}$ As also observed by Dudley Knowles, Pettit "has to go beyond the recital of metaphors of citizens 'looking at each other in the eye' and the like" (1999, 418).

${ }^{13}$ Says Pettit in a summarizing paragraph:

While the republican project of promoting overall freedom as non-domination does imply equally intensifying non-domination, it does not necessarily involve equally extending undominated choice. While the project is committed to structural egalitarianism, as I put it, and while it scores well in this regard, it is not essentially committed to any sort of material egalitarianism. There may be a case for instituting certain material inequalities (...) but it is subject to more empirical contingencies than in the case for establishing structural equality: the case for establishing equality in the intensity with which people enjoy freedom as non-domination. $(1997,119)$

However, as pointed out by Roger Boesche, it is not clear "that freedom as non-domination 'requires' (p. 81) institutions that value equality and general welfare" (1998, 865, his emphasis). He adds, "Pettit thinks that a 'welfare state' (p. 163 ) follows somewhat logically from his principle of freedom" (1998, 865, his emphasis).

${ }^{14}$ Using Pettit's expression -see below - you have to imagine yourself as being part of all "vulnerability classes."

${ }^{15}$ Someone might object that, since the positions are the same, it can be said that is liberalism that collapses into republicanism. My reply to the objection is that, unlike republicanism, liberalism constitutes one of the most important theories in contemporary political philosophy. The burden of proof is thus on the side of republican theorists: They have to show that the theory they advance differs from widely known and discussed liberal theory. To the extent that it does not, it collapses into liberalism, and not the other way around.

${ }^{16}$ See Pettit 1997, 8, 96 and in particular 27-31, which is a section devoted to that issue. Walzer, however, associates republicanism with positive freedom $(1990,20)$. For an excellent review of communitarianism see the work of Stephen Mulhall and Adam Swift (1996 and 2003).

${ }^{17}$ This claim would surprise other theorists of republicanism, like Cynthia Ward (1991), who argue that group-based remedies are inconsistent with the republican view of a public-regarding citizenship that has a collective definition of the common good. At any rate, it is not clear to what extent this critique can be raised to Pettit's republicanism: Although he clearly rejects a notion of positive freedom that requires an active participation of citizens, he appeals to it insofar as it is necessary for his notion of non-arbitrary interference as interference that tracks the interests of citizens. 
${ }^{18}$ In other words, there would be intraclass solidarity yet no interclass solidarity.

${ }^{19}$ Pettit 1997, 55. See quote supra.

${ }^{20}$ In a different light, John Christman has argued that tracking the interests of the those affected by the interference is not sufficient to justify the interference: "even a robber 'tracks' my interests during a robbery predicting that I have a higher order interest to live whether or not I hold onto my wallet. (...) [T] he question is not whether the citizen's interests were taken into account but whether they were taken into account properly and according to just procedures" (1989, 205, his italics). Freedom as non-domination, Christman argues, is then not the 'supreme political value' of a just society as Pettit claims: "the protection of freedom cannot be the most basic principle of justice, since the norms that fix the reference of the concept (the principles that define 'unjust'...) are logically prior to the principle that the state should protect liberty per se" $(1989,203)$.

${ }^{21}$ One could object that, from the fact that people have an interest in $\mathrm{x}$, it does not follow that it is in their best interest to have $\mathrm{x}$ enforced. To that extent, it might be said, my example is wrong. This objection however does not take into account that Pettit introduced the discussion about arbitrariness in order to clarify when is interference justified. His claim was that, if interference with A's freedom furthers the interests of A, then such interference is non-arbitrary and is thus justified. Enforcement is a paradigmatic type of interference. Pettit is then justifying enforcement (banning sodas) in the case of my example.

In a different vein, it seems that a republican government that promotes the common interests and ideas of the citizenry would end up collapsing into a comprehensive morality and thus find itself in conflict with diverse cultural and religious values (Kelly 1999, 93).

${ }^{22}$ Says Pettit, "Like the liberal project, our proposal -our republican proposal— is motivated by the assumption that the ideal [of freedom as non-domination] is capable of commanding the allegiance of the citizens of developed, multicultural societies, regardless of their more particular conceptions of the good" $(1997,96)$.

${ }^{23}$ Quote of Montesquieu, in Pettit 1997, 100. These are not necessarily cases of domination. As long as they are required by the promotion of non-domination, these cases constitute non-arbitrary interference, so they do not constitute cases of domination ex hypothese.

${ }^{24}$ Says Pettit,

A teleological republicanism would fail to satisfy reflective equilibrium if it required intuitively objectionable arrangements. As it happens, I do not believe that such a republicanism, such a consequentialist commitment to freedom as non-domination does fail the test of reflective equilibrium. On the contrary, I think that it makes requirements that reform our considered intuitions only in ways which prove on reflection to be compelling: it is in equilibrium, in this reflective way, with considered intuitions about how things should be politically organized $(1997,102)$.

${ }^{25}$ Pettit recognizes that some constraints are needed. He asks, "How can the state be organized so that state interference involves little or no arbitrariness?" (1997, 171). Constraints are thus needed in order to prevent arbitrary interference from the government. Says Pettit, "My case for constitutionalist constraints is that republican instrumentalities should not be manipulable by those in power" $(1997,172)$. However, he does not refer to the constraints that are needed in order to prevent what he has defined as non-arbitrary interference from the government, that is, interference that furthers the interests of the people and thereby promotes the 'greater goal' of non-domination.

${ }^{26}$ Freeman emphasizes that Rawls's theory does not suffer from this problem (Freeman 2003, 36).

${ }^{27}$ See 1997, 111. His only critique of deontological liberalism does not target liberalism but libertarianism: "Deontological or rights- based liberalism raises questions about whether it could ever be legitimate to have a state; it may seem to make anarchism the only option" (1997, 99). He refers to Robert Nozick's libertarian theory (1974) to illustrate the view he is criticizing. Rawlsian liberalism is clearly not vulnerable to this critique.

${ }^{28}$ Pettit states that "the most crucial difference between enjoying non-domination and enjoying mere non-interference is precisely that no individuals have this sort of power over you" (1997, 25, my italics). That means, equality among all individuals is guaranteed.

${ }^{29}$ Besides, it does not even help to say that the fewer the concepts the better the theory, for in this case it is clear that "P" - freedom as non-domination - includes both "Q" - freedom as non-interference - and "R" - equality-, which are not just distinguishable as elements of $P$, but actually distinguished by Pettit.

${ }^{30}$ Lovett 2003. Lovett, however, does not discuss the relevance of this difference, nor whether the republican account of law is superior than the liberal one. See also Meyerson 1999.

${ }^{31}$ Pettit 1997, 35-50 and 65-6; 2002, 346.

${ }^{32}$ Pettit asks whether the republican tradition is consequentialist or not, and his answer is "It is not possible to quote text and verse on the point, as the choice between teleological and deontological attitudes to freedom as non-domination was never articulated as such within the premodern tradition" (1997, 99-100). He adds, "the republican approach became intertwined in the commonwealthman tradition with a habit of jurisprudential, natural-rights thinking, and had 
a deontological aspect" $(1997,101)$. However, Pettit claims that "there is one aspect of the tradition that suggests a fundamentally teleological look. This is that almost all the main figures treat the question of which institutions do best by freedom as an open, empirical issue, not as a question capable of a priori resolution" $(1997,100)$. This, I think, is a view with which both supporters of deontology or consequentialism could agree. It does not ground the claim that the republican tradition is committed to consequentialism.

${ }^{33}$ I gratefully acknowledge the comments of A.P. Martinich in the preparation of this paper. 


\section{Bibliography}

Bell, Daniel. 2005. "Communitarianism." The Stanford Encyclopedia of Philosophy. Ed. Edward Zalta. (http://plato.stanford.edu/archives/spr2003/entries/republicanism)

Berlin, Isaiah. 1958. Two concepts of liberty. Oxford: Clarendon Press.

Boesche, Roger. 1998. “Thinking about Freedom,” Political Theory 26: 855-73.

Christman, John. 1998. "Republicanism: A Theory of Freedom and Government. Philip Pettit." Ethics 109: 202-6.

De Francisco, Andrés. 2006. A Republican Interpretation of the Late Rawls. The Journal of Political Philosophy 14: 207-88.

Hobbes, Thomas. 2002. Leviathan. Ed. A.P. Martinich. Ontario: Broadview Literary Texts.

Kapust, Daniel. 2004. "Skinner, Pettit, and Livy: The Conflict of the Orders and the Ambiguity of Republican Liberty." History of Political Thought 25: 377-401.

Kelly, Erin. 1999. "Republicanism: A Theory of Freedom and Government. Philip Pettit." The Philosophical Review 108: 90-3.

Knowles, Dudley. 1999. "Republicanism: A Theory of Freedom and Government. Philip Pettit." The Philosophical Quarterly 49: 415-9.

Locke, John. 1988. Two Treatises of Government. Ed. Peter Laslett. Cambridge: Cambridge University Press.

Lovett, Frank. 2006. "Republicanism." The Stanford Encyclopedia of Philosophy. Ed. Edward Zalta (http://plato.stanford.edu/entries/republicanism/)

MacIntyre, Alasdair. 1984. After Virtue. $2^{\text {nd }}$ edn. Notre Dame: University of Notre Dame Press.

Meyerson, Denise. 1999. "Republicanism: A Theory of Freedom and Government. Philip Pettit." The University of Toronto Law Journal 49: 173-6.

Mulhall, Stephen and Adam Swift. 1996. Liberals and Communitarians. $2^{\text {nd }}$ edn. Oxford: Blackwell Publishers.

Mulhall, Stephen and Adam Swift. 2003. "Rawls and Communitarianism." The Cambridge Companion to Rawls. Ed. Samuel Freeman, 460-487, Cambridge: Cambridge University Press.

Nozick, Robert. 1974. Anarchy, State, and Utopia. New York: Basic Books.

Pettit, Philipp. 1997. Republicanism. A Theory of Freedom and Government. Oxford: Clarendon Press.

Pettit, Philip. 2002. "Keeping Republican Freedom Simple: On a Difference with Quentin Skinner." Political Theory 30: 339-356.

Pettit, Philip. 2003. "Republicanism.” The Stanford Encyclopedia of Philosophy. Ed. Edward Zalta. http://plato.stanford.edu/archives/spr2003/entries/republicanism [This was the previous entry on republicanism in The Stanford Encyclopedia of Philosophy] 
Rawls, John. 1971, revised edition 1999. A Theory of Justice. Cambridge Mass.: Harvard University Press.

Rawls, John. 1993. Political Liberalism. New York: Columbia University Press.

Rawls, John. 1997. “The Idea of Public Reason Revisited.” The University of Chicago Law Review 64: 765-807.

Sandel, Michael. 1998. Liberalism and the Limits of Justice. $2^{\text {nd }}$ edn. Cambridge and New York: Cambridge University Press.

Sher, George. 1995. "Rights, Neutrality, and the Oppressive Power of the State." Law and Philosophy 14: 185-201.

Skinner, Quentin. 1998. Liberty before Liberalism. Cambridge: Cambridge University Press.

Taylor, Charles. 1985. Philosophy and the Human Sciences. Philosophical Papers 2. Cambridge: Cambridge University Press.

Taylor, Charles. 1989. Sources of the Self: The Making of the Modern Identity. Cambridge Mass.: Harvard University Press.

Walzer, Michael. 1983. Spheres of Justice. A Defense of Pluralism and Equality. New York: Basic Books.

Walzer, Michael. 1984. "Liberalism and the Art of Separation." Political Theory 12: 315-30.

Walzer, Michael. 1990, “The Communitarian Critique of Liberalism.” Political Theory 18: 6-23.

Ward, Cynthia V. 1991. “The Limits of 'Liberal Republicanism': Why Group-Based Remedies and Republican Citizenship Don't Mix.” Columbia Law Review 91: 581-607. 